\title{
HZ. PEYGAMBER'İN ÜMMÎLİĞİNE FARKLI BİR YAKLAŞIM
}

\author{
A Different Approach to the Prophet Muhammad's Illiteracy
}

\section{İhsan ARSLAN*}

ÖZ: $\mathrm{Bu}$ araștırmada $\mathrm{Hz}$. Peygamber'in ümmîliği metodolojik bakıș açısıyla ișlenmiș, referans kaynağı olarak Temel İslâm Bilimleri alanındaki eserler kullanılmıstır. Yapılan incelemede Rasûlüllah'a nispet edilen ümmîlik kavramının okuma-yazma bilmeme anlamında değil, bir yere mensubiyet seklinde kullanıldığ vurgulanmiștır. Kur'ân'da, Allah Rasûlü'nün okur-yazar özelliğine değinilmediği, Ankabût sûresinin 48. ve Sûrâ sûresinin 52. âyetlerinde ise, onun dinî konularda herhangi bir eğitim süzgecinden gecmediği üzerinde durulmuștur. Bu sebeple Allah Rasûlü'nün ümmî olusu, onun Arap toplumuna veya Ümmül-Kurâ'ya mensubiyeti seklinde anlasılması gerekmektedir. Aile bireylerinin, yakın arkadaslarının okuma-yazma bilmesi, ticarî faaliyetlerin merkezinde bulunması ve kaynaklara yansiyan rivayetlerden hareketle onun okuma-yazma bildiği sonucuna ulaş1miștir.

Anahtar Kelimeler: Hz. Peygamber, okuma-yazma, ümmî, ortam, vahiy.
ABSTRACT: In this study the Prophet Muhammad's illiteracy was processed with a methodological point of view specific to historical studies and works on Basic Islamic Sciences were used as a reference source. In the study, it was emphasized that concept of illiteracy credited to the Messenger of Allah is used for affiliation to somewhere rather than illiteracy. In the Qur'an, the Messenger of Allah's literacy is not mentioned, and it is also emphasized that he does not receive any education in religious matters in the 52 nd verse of Surah Al-'Ankabut and 48th verse of and Surah Ash-Shuraa. For this reason, Prophet Muhammad's illiteracy should be understood as his affiliation to the Arab society or Umm al-Qura. It has been concluded that he knew how to read and write because his family members and close friends also knew, he was at the center of commercial activities and what narrations told in the sources.

Key Words: Prophet Muhammad, literacy, illiteracy, environment, revelation.

\section{GİRIŞ̧}

أم الم المَّى (Bir şeyi kast etmek, birini öne geçirmek, bir topluluğa önder olmak) fiilinden gelen أم kelimesinin ism-i mensubudur. أمتي أم أم kelimesi ise "Anne", bir şeyin asl1 anlamindadır kelimesinin sözlük anlamı ise, bir asla bağlı olan, okuma-yazma bil-

${ }^{*}$ Doç.Dr. Recep Tayyip Erdoğan Üniversitesi İlahiyat Fakültesi İslâm Tarihi Öğretim Üyesi.

e posta: ihsan.arslan@erdogan.edu.tr

Hakemli Araștırma Makalesi | Peer-reviewed Research Article

\begin{tabular}{c|c|c|} 
Başvuru|Submission & Kabul|Accept & Yayın |Publish \\
\hline 28.01 .2019 & 12.03 .2019 & 30.06 .2018 \\
\hline
\end{tabular}


meyen anlamında kullanılmaktadır. Bu kelimenin çoğulu ise أمّان dır. ${ }^{1}$ Ayrıca أمّي kelimesi, anasından doğduğu gibi kalan Arap ümmetine veya Ümmü'l-Kurâ'ya (Mekke'ye) mensup olan, ${ }^{2}$ toplumunun yarat1lışı üzere olan, Arap milletinin özelliklerini taşıyan, fitratı ve yaratılışı gereği kitabı bilmeyen, gaflet ve cehalet içerisinde bulunan, bilgisi az olan ve herhangi bir kitaba inanmayan Araplar için kullanılan genel bir ifadedir. Ümmîlik, âdetleri olduğu için yazmayan ve yazmasını da öğrenmeyen bir topluma DA nispet edilmisstir. ${ }^{3}$ Genel olarak Arap toplumu okumayı ve yazmayı bilmeyen bir yapıya sahipti. Allah, elçisini okuma ve yazma bilmeyen bir topluma göndermiştir. ${ }^{4} \mathrm{Bu}$ sebeple Hz. Peygamber: "Biz, yazmayı ve hesap yapmayı bilmeyen bir toplumuz" ve: "Ben, ümmî bir topluma gönderildim" diyerek bu özelliğe vurgu yapmaktadır. 5 O halde terim olarak ümmî kelimesi; örf ve âdetleri gereği okuma-yazma bilmeyen bir topluma mensup olan, anasından doğduğu gibi kalan, kitabı (vahyi) bilmeyen, gaflet ve cehalet içerisinde bulunan kişiyi ifade etmektedir. Bu sebeple ümmîlik, Arap toplumunun en önemli özelliğidir. Hz. Peygamber de böyle bir toplumun üyesidir. Bu durum, onun okuma-yazma bilmediği anlamina gelmemektedir.

Ümmî kelimesi Kurân-1 Kerîm'de altı yerde geçmektedir. Bu kullanımlardan ikisi tekil; dördü ise çoğul şeklindedir. Tekil şeklindeki kullanımlar, A’râf sûresinde şu şekilde geçmektedir: "Onlar, yanlarındaki Tevrat'ta ve Incil'de yazilı bulduklar Resûle, o ümmî

1 Râğıb el-İsfehânî, Müfredâtü Elfâzi'l-Kurân (Dımeşk: Dâru'l-Kalem, 1992), 85-87; Ebu'l-Fadl Cemâlüddîn Muhammed b. Mukerram b. Manzûr, Lisânü'lArab (Beyrut: Dâru Sâdır, 1990), XII, 22-34; Mecdüddîn Muhammed b. Ya'kûb b. Muhammed Fîrûzabâdî, el-Kâmûsu'l-Muhît (Beyrut: Müessesetü'rRisâle, 1987), 1391-1392; Ziya Şen, "Kur'ân'da Ümmî Kavramı ve Hz. Peygamber'in Ümmiliği”, İslâmî İlimler Dergisi, say1 2 (2006): 203-204; Mertoğlu, Mehmet Suat, "Ümmî", Türkiye Diyanet Vakfi İslâm Ansiklopedisi, 42 (İstanbul: TDV Yayınlar1, 2012), 309-310; Emine Demil, "Ümmî Kavramı ve Hz. Muhammed'in (S.A.V) Ümmiliği”, İhiyat Araştırmaları Dergisi, sayı 7 (2017): 92-96.

2 Râğıb el-İsfehânî, Müfredât, 85; İbn Manzûr, Lisânü'l-Arab, XII, 34; Muhammed Hamdi Yazır, Hak Dini Kur'ân Dili (İstanbul: Eser Neşriyat ve Dağ1tım, 1979), IV, 2297.

3 Râğıb el-İsfehânî, Müfredât, 85-87; İbn Manzûr, Lisânü'l-Arab, XII, 22-34; Fîrûzabâdî, el-Kâmûsu'l-Muhît, 1391-1392.

4 İbn Manzûr, Lisânü'l-Arab, XII, 34.

5 İbn Manzûr, Lisânü'l-Arab, XII, 34. 
peygambere uyan kimselerdir. $O$, onlara iyiliği emreder, onları kötülükten alıkoyar. Onlara iyi ve temiz şeyleri helâl, kötü ve pis şeyleri haram kılar. Üzerlerindeki ağır yükleri ve zincirleri kaldırır. Ona iman edenler, ona saygı gösterenler, ona yardım edenler ve ona indirilen nura (Kur'an'a) uyanlar var ya, işte onlar kurtuluşa erenlerdir." "Ey Muhammed!) De ki: "Ey insanlar! Şüphesiz ben, yer ve göklerin hükümranliğ kendisine ait olan Allah'in hepinize gönderdiği peygamberiyim. O'ndan başka hiçbir ilâh yoktur. $O$, diriltir ve öldürür. O hâlde, Allah'a ve O'nun sözlerine inanan Resûlüne, o ümmî peygambere iman edin ve ona uyun ki doğru yolu bulasınız." Bu iki âyette geçen "Ümmî" kelimesiyle kastedilen Hz. Peygamber'dir.

Ümmî kelimesinin diğer kullanımları ise şu şekildedir: "Bunların bir de ümmî takımı vardır; Kitab'ı (Tevrat'ı) bilmezler. Onların bütün bildikleri bir sürü kuruntulardır. Onlar sadece zanda bulunurlar."8 Bu âyette çoğul olarak kullanılan ümmî kelimesi, Allah'ın hayatları hakkında bilgi verdiği ve Rasûlüllah'ın ashâbının imanlarından ümidini kestiği Yahudiler, okuma-yazma bilmeyen Yahudiler, Allah'in gönderdiği elçileri ve indirdiği kitabı tasdik etmeyenler, ${ }^{9}$ okumayazma bilmeyen münafiklar ve Yahudiler, okuma-yazma bilmeyen Ehl-i kitap, işledikleri günahlardan dolayı kitapları kaldırılanlar veya mecûsîlerdir. ${ }^{10}$ Diğer kitaplar hakkında yeterince bilgi sahibi olmadıkları halde Tevrat'ı mütalaa eden ve onu incelemeye çalışanlardır. ${ }^{11}$ Câbirîyye göre âyette geçen ümmî kelimesi, Yahudiliği benimsemiş olan, fakat Tevrat'i bilmeyen ve kendi uydurdukları şeyleri Tevrat diye öne süren bazı Araplardır. ${ }^{12} \mathrm{Bu}$ sebeple âyette geçen "Ümmîler" kelimesini bütün tefsirciler, "Okuma-yazma bilmeyen Yahudiler" olarak anlama eğilimindedirler. Oysa Kur'ân ve hadislerde geçen

\footnotetext{
${ }^{6}$ A'râf: $7 / 157$.

7 A'râf: $7 / 158$.

8 Bakara: $2 / 78$.

9 Ebû Ca'fer Muhammed b. Cerîr et-Taberî, Câmiu'l-Beyân an Te'vîli Âyi'lKur'ân (Kahire: Dâru'l-Hadîs, 2010), I, 560-561.

10 Ebû Abdullah Muhammed b. Abdullah el-Kurtubî, el-Câmî li Ahkâmi'lKur'ân (Kahire: Dâru'l-Hadîs, 2010), I, 430.

11 Ebu'l-Kâsım Cârullah Muhammed b. Ömer b. Muhammed ez-Zemahşerî, elKeşşâf (Beyrut: Dâru'l-Kütübi'l-Ilmiyye, 2009), I, 158.

12 Muhammed Âbid el-Câbirî, Kur'ân'a Giriş, çev. Muhammed Çoşkun (İstanbul: Mana Yayınları, 2013), 91-92.
} 
"Ümmî", "Ümmîler", "Ümmî ümmet" gibi ifadelerin hiçbirisi okumayazma bilmeme anlamında değildir. ${ }^{13}$ Çünkü Taberî, Dahhâk’ın, İbn Abbâs'tan şöyle bir rivayette bulunduğunu rivayet etmektedir: “Ümmîler, Allah'ın gönderdiği hiçbir elçiye ve kitaba inanmayıp kendi kutsal kitaplarinı kendi elleriyle yazan ve sözlerine kanacak kimi zavallilara "Bu kitap Allah'tan gelmiştir"14 diyenlerdir. Kur'ân onlarin, kitaplarinı elleriyle yazdıklarin haber vermiss ${ }^{15}$ ve Allah'in kitaplarin ve elçilerini inkâr ettikleri için onlar "Ümmîler" diye adlandırmıştır."16 rivayet bunu doğrulamaktadır. ${ }^{17}$

"Seninle tartışmaya girişirlerse, de ki: "Ben, bana uyanlarla birlikte kendi özümü Allah'a teslim ettim." Kendilerine kitap verilenlere ve ümmîlere de ki: "Siz de İslâm'ı kabul ettiniz mi?" Eğer İslâm'a girerlerse hidayete ermiş olurlar. Yok, eğer yüz çevirirlerse sana düşen şey ancak tebliğ etmektir. Allah, kullarını hakkıyla görendir."18 Burada kullanılan "Ümmîler" kelimesiyle kendilerine kitap verilmeyen müşrik Araplar kastedilmektedir. ${ }^{19}$

"Kitap ehlinden öylesi vardır ki, ona yüklerle mal emanet etsen, onu sana (eksiksiz) iade eder. Fakat onlardan öylesi de vardir ki, ona bir dinar emanet etsen, tepesine dikilip durmadikça onu sana iade etmez. Bu da onların, "Ümmîlere karşı (yaptıklarımızdan) bize vebal yoktur" demelerinden dolayıdır. Onlar, bile bile Allah'a karşı yalan söylerler." ${ }^{\prime \prime} \mathrm{Bu}$ âyette geçen "Ümmîler" kelimesiyle Müslüman Araplar kastedilmektedir. Çünkü Yahudiler cahiliye döneminde bazı müşriklerle alış-veriş yapıyorlardı. Bu müşrikler İslâm'a girince Yahudiler onlara olan borçlarını ödeyerek: "Sizlere karşı herhangi bir borcumuz bulunmamaktadır. Sizler eski dininizi değiștirip Müslüman olduğu-

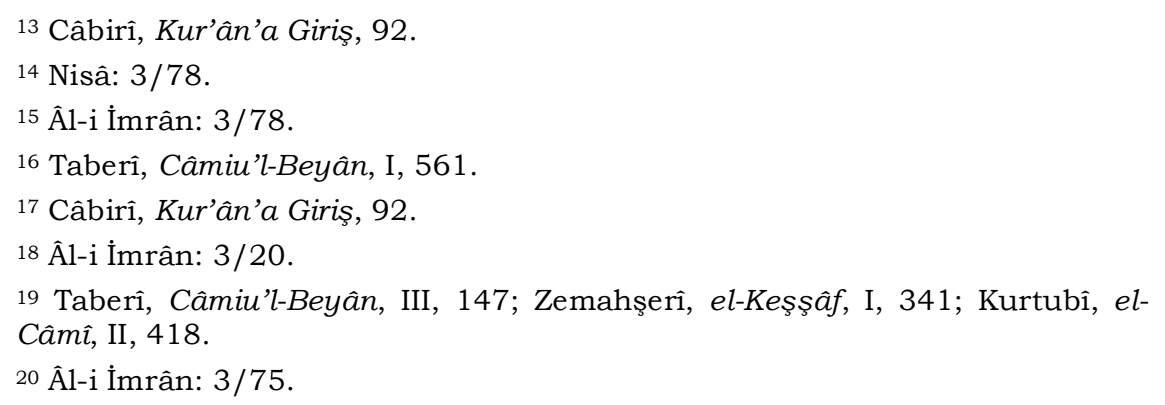


nuzdan dolayı sizlerle bizim aramızda herhangi bir bağ kalmamıştır"21 diyerek Müslümanlardan ilişkilerini kesmişlerdir.

"O, ümmîlere, içlerinden, kendilerine âyetlerini okuyan, onlar temizleyen, onlara kitabı ve hikmeti ögreten bir peygamber gönderendir. Hâlbuki onlar, bundan önce apaçık bir sapıklık içinde idiler." $22 \mathrm{Bu}$ âyette "Ümmîler" kelimesiyle Araplar kastedilmektedir. ${ }^{23}$

Yukarıdaki âyetlerde çoğul olarak kullanılan "Ümmîler" kelimesiyle okuma-yazma bilmeyenler değil, kendilerine kitap verilmeyen Araplar, Ehl-i kitap ve Müslüman Araplar kastedilmektedir. Bunlar arasındaki temel fark; vahiy kaynaklı bir kitaba sahip olup olmamalarıdır.

Hz. Peygamber: "Biz, okumayı ve hesap yapmayı bilmeyen ümmî bir ümmetiz"24 diyerek yaşadığ1 toplumun özelliğine vurgu yapmaktadır. Câbirî bu cümlenin iki şekilde yorumlanabileceğini şu şekilde belirtmektedir:

1- Birinci yoruma göre, burada "hesap kitap bilmeyiz" ifadesi, ümmî olmanın bir özelliği olarak düşünülebilir. O zaman cümle şu anlama gelebilir: "Biz, hesap kitap bilmeyen türden bir ümmî bir ümmetiz."

2- İkinci yoruma göre ise, "hesap kitap bilmeyiz" ifadesi, ümmî olmanın açıklayıcısıdır. Buna göre, "hesap kitap bilmeyiz" kayd1, ümmî ümmet olmanın ne anlama geldiğini açıklamaktadır. Dikkat edilirse her iki durumda da "Ümmîlik" kelimesinin hesap ve kitap bilmeme anlamına gelmesi imkânsızdır. Çünkü kelimeye bu anlam verildiği takdirde hadisin anlamı şöyle olacaktır: "Biz hesap kitap bilmeyen bir ümmetiz. Hesap kitap bilmeyiz." Görüldüğü gibi burada anlamsız bir tekrar ortaya çıkmaktadır. Böylece, "ümmîlik" ile "hesap

21 Taberî, Câmiu'l-Beyân, III, 279-281; Zemahşerî, el-Keşşâf, I, 367; Kurtubî, el-Câmî, II, 483.

22 Cum'a: 62/2.

23 Taberî, Câmiu'l-Beyân, X, 800; Zemahşerî, el-Keşşâf, IV, 517; Kurtubî, elCâmî, IX, 337.

${ }^{24}$ Ahmed b. Hanbel, Müsned (İstanbul: Çağrı Yayınları, 1992), II, 43; Buhârî, Ebû Abdullah Muhammed b. İsmail el-Buhârî, Sahîhu'l-Buhârî (İstanbul Çağrı Yayınları, 1992), Savm, 13; Ebu'l-Huseyin Müslim b. Haccâc b. Müslim, Sahîhu Müslim (İstanbul: Çağrı Yayınları, 1992), Sıyâm, 15. 
kitap bilmeme"nin birbirinden farklı şeyler olduğu açıkça anlaşılmış olmaktadir. ${ }^{25}$

Kur'ân'da tekil olarak kullanılan "ümmî̋" kelimesiyle Hz. Peygamber, çoğul olarak kullanılan "ümmiyyûn" kelimesiyle de Müslüman Araplar, müşrik Araplar ve Ehl-i kitap kastedilmektedir. Konumuzla ilgili olan A'râf sûresinin 157 ve 158. âyetlerinde Hz. Peygamber'in sıfatı olarak kullanılan ümmî kelimesinin nasıl anlaşılması gerektiğidir. Rasûlüllah'ın sıfatı olarak belirtilen bu kelime genelde "okuma-yazma bilmeyen" anlamında anlaş1ldı̆ için onun okumayazma bilmediğine vurgu şeklinde anlaşılmıştır. Ancak "ümmî" kelimesinin ism-i mensup olduğu üzerinde durulmadığ1 için "okumayazma bilmeme" anlamı ön plana çıkmıştır. Gramatik açıdan Allah Rasûlü'nün sıfatı olan kelime, onun ait olduğu toplumu göstermektedir. Yani âyette onun Mekkeli olduğuna vurgu yapılmaktadır. Bu çalışma, Hz. Peygamber'in sıfatı olan "ümmî" olma durumunun, okuma-yazma bilmeme anlamında olmadığını ortaya koymayı hedeflemektedir.

\section{A- Hz. Peygamber'in Okuma-Yazma Bilmediğini Savunanla- rin Görüşleri}

1- "Onlar, yanlarndaki Tevrat'ta ve İncil'de yazıl bulduklar Resûle, o ümmî peygambere uyan kimselerdir. $O$, onlara iyiliği emreder, onları kötülükten alıkoyar. Onlara iyi ve temiz şeyleri helâl, kötü ve pis şeyleri haram kılar. Üzerlerindeki ağır yükleri ve zincirleri kaldtrir. Ona iman edenler, ona saygı gösterenler, ona yardım edenler ve ona indirilen nura (Kur'an'a) uyanlar var ya, işte onlar kurtuluşa erenlerdir."26 "(Ey Muhammed!) De ki: "Ey insanlar! Şüphesiz ben, yer ve göklerin hükümranliğı kendisine ait olan Allah'in hepinize gönderdiği peygamberiyim. O'ndan başka hiçbir ilâh yoktur. $O$, diriltir ve öldürür. O hâlde, Allah'a ve O'nun sözlerine inanan Resûlüne, o ümmî peygambere iman edin ve ona uyun ki doğru yolu bulasinız." 27

\footnotetext{
${ }^{25}$ Câbirî, Kur'ân'a Giriş, 93.

26 A'râf: $7 / 157$.

27 A'râf: $7 / 158$.
} 
2- "Sen şu Kur'an'dan önce hiçbir kitap okumuyor ve onu săg elinle yazmıyordun. (Okuyup yazsaydın) o takdirde batıl pessinde koşanlar, şüpheye düşerlerdi."28

3- Rasûlüllah Hirâ mağarasındayken melek gelerek: "Oku/Söyle" dedi. Hz. Peygamber: "Ne okuyayım/Ne söyleyeyim" deyince melek, onu takatten kesilinceye kadar s1ktı ve tekrar: "Oku/Söyle" dedi. Rasûlüllah: "Ne okuyayım/Ne söyleyeyim" dedi. Melek yine onu takatten kesilinceye kadar s1kt1 ve tekrar: "Oku/Söyle" dedi. Allah Rasûlü: "Ne okuyayım/Ne söyleyeyim" dedi. Bunun üzerine melek: "Yaradan Rabbinin adıyla oku" dedi ve Alak sûresinin ilk beş âyetini okudu. ${ }^{29}$

4- Hz. Peygamber'in okuma-yazma bilmediği hem ashâb hem de müşrikler tarafindan bilinen bir gerçekti. Sahâbîler, Rasûlüllah'in bütün hayatını en ince ayrıntılarına kadar hatta eşleriyle özel ilişkileri varıncaya kadar kayıt altına almışlar, vakıf oldukları her şeyi rivayet etmişlerdir. Ama bu rivayetler içerisinde onun okur-yazar olduğuna dair hiç bir kayıt yoktur. Diğer taraftan Hz. Peygamber’in yaşadığı dönemde Mekke fazla geniş olmayan bir çevreye sahipti. Mekkeliler onun her anını biliyorlardı. O, herhangi bir okula gitmemiss. Mekke'de sayısı zaten pek az olan okur-yazarlarla oturup kalkmamiş, onlardan bir şeyler öğrenmemiş, ticarî seferlerinde uzun süre bir yerde konaklamamıştır. Şayet o, bu şekillerden biriyle okumayazma öğrenseydi, nübüvvetini inkâr için bin bir sebep arayan ve yoktan iftiralar uyduran müşrikler bir mesned bulmuş, bir firsat yakalamış olurlar, itirazlarını ayyuka çıkarır ve gönüllere şüpheler sokarlardı. Onlar, Rasûlüllah'ın okur-yazar olmadığını kesinlikle bildikleri için böyle bir şey meydana gelmemişti. ${ }^{30}$

5- Hz. Peygamber gündüz, gece, yalnız, namazda ve hatta uykuda gibi çeşitli zaman ve durumlarda vahye muhatap olurdu. Bu

\footnotetext{
28 Ankebût: 29/48.

29 Buhârî, Bed'ü'l-Vahy, 1; Müslim, İmân, 252.

30 Abdu's-Sabûr Şâhin, "Hz. Muhammed Okumayı ve Yazmayı Biliyor muydu?", çev. Tayyar Altıkulaç, Diyanet İlmi Dergi 12, say1 4 (1973): 199; Muhammed Rıza, Muhammed (Beyrut: Dâru'l-Kalem, 2003), 70; Ahmet Önkal, "Hz. Peygamber'in Ümmîliği”, Konya Selçuk Üniversitesi Ilahiyat Fakültesi Dergisi, say1 2 (1986): 251; Afzalur Rahman, Sìret Ansiklopedisi, çev. Komisyon (İstanbul: İnkılâb Yayınları, 1996), III, 200-204.
} 
durumlarda onun yanında vahiy kâtipleri bulunmayabiliyordu. O, yanında kâtip yokken vahiy geldiği esnada okuma-yazma bilseydi, gelen vahiyleri kendisi yazabilirdi. Ancak vahyin bu şekilde yazıya geçirildiğine dair herhangi bir mevsuk, zayıf hatta merdûd tek bir rivayet bile yoktur. Allah Rasûlü gelen vahiyleri zaptetmek için çok çok mücadele ettiği için Allah, onu bu konuda sakinleştirmek için âyetler göndermiştir. ${ }^{31}$ Şayet o, okuma-yazma bilseydi, kâtipleri yokken bu vahiyleri yazar ve sıkıntıya düşmezdi. ${ }^{32}$

6- Bedir Savaşı'nda yakınlarını kaybeden Mekkeliler, Mekke'nin lideri konumunda olan Ebû Süfyân'a gelerek Müslümanlardan kurtarılan kervandan elde edilen kârın, Hz. Peygamber'den ve Müslümanlardan intikam almak için asker toplanmasında harcanmasını teklif ettiler. Bu teklifi Ebû Süfyân yerinde bularak asker toplamak için komşu ve çevre kabilelere görevliler gönderdi. Yapılan propaganda çalışmaları neticesinde üç bin kişiden müteşekkil olan bir ordu hazırlayarak Medine'ye doğru hareket ettiler. Bunun üzerine Abbâs b. Abdilmüttalib Kureyş’in savaş hazırlıklarını, asker, hayvan sayıs1n1 ve silah durumunu bir mektupla bildirmek amaciyla Benû Gıfâr'dan olan bir kişiyi üç gün içinde Medine'ye gitmesi karşılığında ücretli olarak tuttu. Bu şahıs Kubâ'da Hz. Peygamber'i bularak mektubu kendisine verdi. Rasûlüllah mektubu Übey b. Ka'b'a okutarak içindekilere muttali oldu ve bunu hiç kimseye söylememesini belirtti. ${ }^{33} \mathrm{~Hz}$. Peygamber okuma-yazma bilseydi, böyle önemli bir mektubu kendisi okur ve haberin gizli tutulmasını bașka birisinden istemezdi. ${ }^{34}$

7- Hz. Peygamber'in, Abdullah b. Sa'd b. Ebî Serh isimli bir vahiy kâtibi vardı. Bu şahıs, vahyin önemini anlamamış olacak ki, bazı âyetleri değiştirerek yazıyordu. Örneğin Rasûlüllah ona: "غفورا رحيما " yazmasını söylediği halde o: "عليما حكيما" sseklinde yazıyordu. Allah Rasûlü ona: "سميعا" yazmasin1 söylerdi o da: "سميعا بصير" şeklinde yazard1. Yine Hz. Peygamber ona: "عليما حكيما" yazmasını söylerdi o da:

${ }^{31}$ Kiyâme: 75/16-19; A’lâ: 87/6.

32 Şâhin, "Hz. Muhammed Okumayı ve Yazmayı Biliyor muydu?", 199; Rıâ, Muhammed, 71; Önkal, "Hz. Peygamber'in Ümmîliği”, 252.

33 Muhammed b. Sa'd, et-Tabakâtü'l-Kübrâ (Beyrut: Dâru'l-Kütübi'l-Ilmiyye, 1990), II, 28; Rizâ, Muhammed, 71.

${ }^{34}$ Rizâ, Muhammed, 71. 
" عليما حليما" şeklinde yazard1. Hz. Peygamber de her defasında ona doğrusunu yazmasını söylüyordu. Bu şahıs dinden dönüp Mekke'ye gittiğinde müşriklere: "Muhammed'e istediğim şekilde yazıyordum" diyerek vahyi değiştirdiğini belirtmeye çalışmıştır. ${ }^{35}$

8- Hudeybiye Antlaşması'nın sağladığı barış ortamından dolayı Medine'ye çevre bölgelerden heyetler gelmeye bassladı. Bu heyetler arasında Sakîf heyeti de bulunmaktaydı. Sakîf heyeti İslâm'a girdikten sonra Hz. Peygamber'den kendilerine bazı şartlar içeren resmi belge vermelerini istediler. Bunun üzerine Rasûlüllah onların isteğini yerine getirin ve sonra da yazdıklarınızı bana getiriniz, dedi. Resmi belge yazllırken Sakif heyeti, içkinin ve zinanın kendilerine helal olmasını istedi. Ancak Ali b. Ebî Tâlib onların bu isteğini yerine getirmedi. Onlar da Hâlid b. Saîd'den yardım istediler. Hz. Ali, Saîd'e: "Yazacağın şeyin ne olduğunu biliyor musun? diye sordu. Hâlid: "illk önce Rasûlüllah'ın ve onların dediklerini yazacağım" diye cevap verdi. Yazılan resmi belge Allah Rasûlü'ne getirilince yanında bulunan kişiye "Okumasını" söyledi. Kârî, ribanın yazılı olduğu yeri okuyunca Hz. Peygamber: "ضع يدي عليها" "Elimi o cümlenin üzerine koy" dedi. Görevli, Rasûlüllah'ın elini ribanın yazılı olduğu cümlenin üzerine koyunca o: "Ey Iman edenler! Allah'tan korkun ve gerçekten iman etmiş kişilerseniz, faizden geriye kalanı birakın."36 âyetini okuyarak o kısmı metinden çıkardı. Görevli zinanın yazılı olduğu cümleyi okuyunca Hz. Peygamber ribaya karşı takındığı tavrın aynısını gösterdi ve: "Zinaya yaklaşmayın. Çünkü o, son derece çirkin bir iştir ve çok kötü bir yoldur." 37 âyetini okuyarak bu kısmı metinden çıkardı. Eğer Rasûlüllah okuma-yazma bilseydi, "elimi bu cümlenin üzerine koyun" diyerek başkasının göstermesine gereksinim duymadan resmi belgede belirtilen ilgili kısımları kendisi silerdi. ${ }^{38}$

9- Hz. Peygamber 628 yılında bir grup Müslüman ile birlikte Kabe'yi tavaf etmek amacıyla Medine'den Mekke'ye doğru yola çıktı. Kureyş’in, Müslümanların bu düşüncesini yerine getirmelerine engel olacağını öğrenen Allah Rasûlü Hudeybiye denilen yerde konaklama-

\footnotetext{
35 Ahmed b. Hanbel, Müsned, III, 121, 245.

36 Bakara: 2/278.

37 İsrâ: $17 / 32$.

38 Rızâ, Muhammed, 71.
} 
y1 uygun gördü. İki taraf arasında elçilerin müzakeresinden sonra anlaşmaya varıld1. Hz. Peygamber, anlaşmanın başına "Bismillahirrahmanirrahîm" yazılmasını emretti. Kureyş’in delegesi olan Süheyl b. Amr: "Biz Rahman ve Rahîm'in ne anlama geldiğini bilmiyoruz" diyerek buna itirazda bulundu ve anlassmaya "Bismikallahümme" cümlesiyle başlanılmasını istedi. Onun isteği doğrultusunda cümle değiştirildi. ${ }^{39}$ Daha sonra Allah Rasûlü, kâtibi Ali b. Ebî Tâlib'e: "Bu Allah'ın Rasûlü Muhammed ile Suheyl b. Amr arasında imzalanan sulh antlaşmasıdır" cümlesini yazmasını istedi. Kureyş delegesi: "Biz senin Allah'ın Rasûlü olduğunu bilmiş ve tasdik etmiş olsaydık, seni Kâbe'yi ziyaret etmekten men etmez ve seninle savaşmazdik" diyerek buna da itirazda bulundu ve: "Rasûlüllah" kısmının kaldırılıp yerine "Muhammed b. Abdullah" yazılmasını talep etti. Bunun üzerine Rasûlüllah, Ali b. Ebî Tâlib'e "Rasûlüllah" lafzını silip "Muhammed b. Abdullah" yazmasinı emretti. Ancak Ali b. Ebî Tâlib: "Rasûlüllah lafzını asla silemeyeceğini” söyledi. Ali b. Ebî Tâlib’in kararlılığını gören Rasûlüllah: "ارني مكانها” “Onun yerini bana göster" dedi. Ali b. Ebî Tâlib, Allah Rasûlü'ne yerini gösterince o, "Rasûlüllah" lafzını sildi ve "Muhammed b. Abdullah" ibaresini yazd1.40 Eğer Rasûlüllah okumayazma bilseydi, Hz. Ali'ye "Onun yerini bana göster" demeye ihtiyaç duymadan ilgili kısmın yerini kendisi bulur ve gereken değişikliği yapard1.

\section{B- Görüşlerin Değerlendirilmesi}

1- A'râf sûresinin 157. ve 158. âyetlerinde kullanilan "ümmî" kelimesi, Hz. Peygamber'in sıfatı olarak kullanılmıştır. Burada ümmî kelimesinin kullanımını Arap toplumuna veya Ümmü'l-Kurâ'ya mensup anlaminda alırsak, ${ }^{41}$ onlar "Arap toplumuna veya ÜmmülKurâ'ya mensup olan bir elçiye uyarlar" şeklinde bir anlam vermek mümkündür. Eğer ümmî kelimesine okuma-yazma bilmeyen anlamı

\footnotetext{
${ }^{39}$ Abdülmelik b. Hişâm, es-Sìretü'n-Nebeviyye (Kahire: Dâru İbn Kesîr, ts), IIIIV, 317, Buhârî, Şurût, 15; İbn Sa'd, et-Tabakâtü'l-Kübrâ, II, 77.

40 İbn Hişâm, es-Sìratü'n-Nebeviyye, III-IV, 317, Buhârî, Meğâzî, 43, Sulh 6; Müslim, Cihâd, 92; Ebu'l- Fidâ İsmail b. Kesîr, el-Bidâye ve'n-Nihâye (Kahire: Dâru'l-Hadîs, 1994), IV, 169; Muhammed Abdülhay b. Abdülkebir el-Kettânî, et-Terâtîbü'l-İdarriyye, çev. Ahmet Özel (İstanbul: İz Yayınclik, 1990), I, 249253.

41 Râğıb el-İsfehânî, Müfredât, 85; İbn Manzûr, Lisânü'l-Arab, XII, 34; Yazır, Hak Dini Kur'ân Dili, IV, 2297.
} 
verirsek, ${ }^{42}$ onlar "Okuma-yazma bilmeyen bir elçiye uyarlar" şeklinde anlaşılması gerekmektedir. Ancak bu âyetlerde nebî ve rasûl kelimelerinin bir sıfatı olarak kullanılan "ümmî" kavramını, Hz. Peygamber'in okuma-yazma bilmediği anlamında değil, onun ait olduğu toplum şeklinde anlamak daha doğru olur. Yani burada onun, Mekke toplumuna mensup biri olduğuna vurgu yapılmaktadır. Çünkü bu âyetlerde geçen "Onlar ümmî olan nebiye-rasûle itaat ederler"43 ve "Ümmî olan nebiye-rasûle iman ediniz"44 ifadelerinden okuma-yazma bilmeyen anlamını çıkarmak, âyetin bağlamına uygun düşmez. Onların tanıdıkları birine itaat ettikleri ve içlerinden olan birine iman ettikleri vurgulanmaktadır. O halde onlar Mekkeli olan birine itaat etmekte ve ona inanmaktadırlar.

2- Hz. Peygamber'in okuma yazma bilmediğini savunanların öne sürdüğü en güçlü delil; "Sen şu Kur'an'dan önce hiçbir kitap okumuyor ve onu sağ elinle de yazmıyordun." 45 âyetidir. Kur'ân âyetlerinin bağlamı iki hususun birlikte dikkate alınmasıyla tespit edilir: 1- Ele alınan âyetin öncesinde ve sonrasında yer alan âyetlerden oluşan pasaj. 2- Âyetin nüzul şartları -yani içerisinde yer aldığı sûrenin nüzul sıralamasındaki yeri- diğer âyetlerle ilişkisi ve muhatap kitlesinin açıklığa kavuşturulması. Bu iki hususa ilave olarak da "Kur'ân'ın kimi âyetleri kimi âyetlerini açıklar" prensibi dikkate alınmalıdır. ${ }^{46}$ Ankebût sûresinin konumuzla ilgili olan âyeti Mekke döneminde nâzil olmuştur. ${ }^{47} \mathrm{~Hz}$. Peygamber İslâm'ı tebliğ etmeye başladığ1 andan itibaren müşriklerin yoğun tepkisiyle karş1laşmış ve Kur'ân-1 kendisinin yazdığı veya biri tarafından öğretildiği ithamına muhatap olmuştur. Bu sebeple hakikatin onların dediği gibi olmad1ğını ortaya koymak ve daha sonraki dönemlerde bu ve bunun gibi ithamlara mahal bırakmamak için ilgili âyeti ilahî uyarı niteliğinde bir cevap şeklinde değerlendirmek mümkündür. Mâtürîdî bu âyetin yorumunda şu düşüncelere yer vermektedir: "Sen vahiy gelmeden

\footnotetext{
42 Râğı el-İsfehânî, Müfredât, s. 85-87; İbn Manzûr, Lisânü'l-Arab, XII, 22-34; Fîrûzabâdî, el-Kâmûsu'l-Muhît, 1391-1392.

43 A'râf: $7 / 157$.

${ }^{44}$ A'râf: $7 / 158$.

45 Ankebût: $29 / 48$.

46 Câbirî, Kur'ân'a Giriş, 102.

47 Zemahşerî, el-Keşşâf, III, 424; Kurtubî, el-Câmî, VII, 287.
} 
önce herhangi bir kitap okumuyordun. Eğer okusaydın, onlar: "Kendilerine, senin önceki peygamberlerden veya hikmetli sözlerden haber verdiğini ve bu vahyi önceki kitaplardan veya hikmetli kitaplardan aldiğını söylerlerdi." Eğer sağ elinle de yazsaydın, onlar: "Senin, bunlar oluşturup ortaya koyduğunu söylerlerdi."48 Yani Mâtürîdî, ilgili âyetin okuma ve yazmayla ilgili olmadığını, Hz. Peygamber'in vahiy almadan önce herhangi bir dinî içerikli eğitim süzgecinden geçmediğini belirtmektedir.

Âyete literal olarak bakıldığında Rasûlüllah'ın risâlet öncesi okumasının ve yazmasının olmadığını söylemek ihtimal dâhilindedir. Ancak buradaki okuma ve yazma konusunu, bir kişinin gerçek anlamda okuma ve yazma bilmediği sseklinde değerlendirmek uygun değildir. Burada vurgulanan asıl nokta; Hz. Peygamber'e yapilan ithamlara karşı verilen cevaptır. Çünkü Kur'ân, inanmayanların, vahyin Hz. Peygamber tarafından yazıldığına dair söylemlerini belirtmektedir: "İnkâr edenler, "Bu Kur'ân, Muhammed'in uydurduğu bir yalandan başka bir şey değildir. Başka bir topluluk da bu konuda ona yardım etmiştir" dediler. Böylece onlar haksız ve asılsız bir söz uydurdular." 49 "Müşrikler şöyle dediler: Bu Kur'ân, Muhammed'in birilerine yazdırdiğı ve ezberlemesi için de sabah akşam kendisine okunan eskilerin masallarindan ivbarettir."”50 "Andolsun ki biz onlarn, "Kur'ân'ı ona bir insan ögretiyor" dediklerini biliyoruz." 51 Bu âyetlerde Hz. Peygamber'e yöneltilen ithamlar açık bir şekilde görülmektedir. Ankebût sûresinin 52 48. âyeti ise bu ithamları ortadan kaldırmaktadır. O halde Hz. Peygamber'in okuma-yazma bilmemesi; riâlet öncesi vahiy konusunda ve dini konularda herhangi bir eğitim sürecinden geçmediği anlamındadır. Ayrıca onun insanlara tebliğ ettiği öğretiler, Allah tarafindan kendisine bildirilen şeylerdir. Yani Allah Rasûlü, vahyi herhangi bir insandan değil, ilahî kanaldan almıştır. Diğer ta-

48 Ebû Mansûr Muhammed b. Muhammed b. Mahmud el-Mâtürîdî, Te'vîlâtü Ehli's-Sünne, Müesesetü'r-Risâle, Beyrut 2004, IV, 23.

49 Furkân: 25/4.

50 Furkân: 25/5.

51 Nahl: 16/103.

52 Ankebût sûresi hakkında geniş bilgi için bkz. Muhammed Yımaz, İbadete Karşı Toplumsal Tavırlar Ankebût Sûresi Örneği (İstanbul: Erkam Yayınları, 2016), 37-141. 
raftan Rasûlüllah, Yahudi ve Hristiyan bilginler gibi daha önceki ilahî kitaplar hakkında derin bir bilgiye sahip değildir. O, Mekke toplumunda da herhangi bir dini eğitim de almamıştır. Eğer o, bu yönde bir eğitim almış olsayd1, insanlar tarafından mutlaka bilinirdi. "Insanlar (vahiy hakkında) şüpheye düşerlerdi" 53 âyeti bunun en güzel delilidir. Ayrıca "Sen bundan önce kitap nedir, iman nedir bilmezdin" 54 ve "Sen bu kitabın sana verileceğini ummuyordun" 55 âyetleri de $\mathrm{Hz}$. Peygamber'in risâletten önce herhangi bir dini eğitim sürecinden geçmediğini göstermektedir. O halde vahyin kaynağ $\mathrm{Hz}$. Peygamber değil, Allah'tır.

3- İlk vahiy esnasında Hz. Peygamber’in Cebrâil ile karş1laşmas1 ve ikisi arasında geçen diyalogdan hareketle onun okuma-yazma bilmediğini söylemek uygun değildir. Çünkü konu Hz. Peygamber’in okuma ve yazma bilgisini ölçmek değildir. Rasûlüllah'ın Cebrâilin ي ما انا بقارئ şeklinde verdiği cevap ${ }^{56}$ onun okuma bilmediğini göstermektedir. Ancak bu okumayı olumsuzlama şekli; vahiy konusundadır. Yani Allah Rasûlü'nün vahiy almaya başlamadan önce dinî konularda eğitim almadığı için "Ben okuma bilmem" şeklinde cevap vermesi mümkündür. İlk vahiy esnasinda Hz. Peygamber’in Cebrâil ile arasında geçen konuşmayı anlatan Taberî, Rasûlüllah'ın ب ما أقرأ؟ emrine okuyayım? / Neyi okuyayım?) şeklinde soruyla cevap vermesi, 57 onun daha önce okuma ve yazma bildiğini göstermektedir. Kaynaklarda Hz. Peygamber'in Cebrâil'in emrine verdiği cevap iki farklı şekilde belirtilmektedir. Bu sebeple Rasûlüllah'ın ilk defa yaşadığı vahiy tecrübesi esnasında Cebrâil ile arasında geçen karş11ıklı konuşma, onun okuma ve yazma bilmediğini ortaya koymaz.

\footnotetext{
53 Ankebût: 29/48; Bkz. Seyyid Ebu'l-Alâ Mevdûdî, Tefhîmü'l-Kurân, çev. Komisyon (İstanbul: İnsan Yayınlar1, 1991, IV, 262-265; Seyyid Ebu'l-Alâ Mevdûdî, Tarih Boyunca Tevhid Mücadelesi ve Hz. Peygamber'in Hayatı, çev. Ahmed Asrar (İstanbul: Pinar Yayınları, 1992), I, 94-102.

54 Şûrâ: $42 / 52$.

55 Kasas: $28 / 86$.

56 Buhârî, Bedü'l-Vahy, 1, Müslim, İmân, 252.

${ }^{57}$ Ebû Ca'fer Muhammed b. Cerîr et-Taberî, Târîhu'l-Ümem ve'l-Mülûk (Beyrut: Dâru'l-Kütübi'l-Ilmiyye, 1997), I, 531-532.
} 
4- Hz. Peygamber, amcası Abbâs b. Abdilmüttalib Kureyş'in savaş hazırlıklarını, asker, hayvan sayısını ve silah durumunu bir mektupla bildirmek amacıyla Benû Gıfâr'dan olan şahısla göndermiş olduğu mektubu, Ubey b. Ka'b'a okutarak muhtevasını öğrenmesi, okuma bilmediğine bir delil teşkil etmez. Çünkü devlet başkanları veya idareciler kendilerine gelen mektuplar (devletin, vatanın ve milletin güvenliği ile ilgili konularda) ne kadar önemli olursa olsun, güvendikleri kişilere okutmalarında bir sakınca görmezler. Bu durum, onların okuma ve yazma bilmediklerini göstermez. Rasûlüllah da bir devlet başkanı ve idareci olduğundan gelen mektubu o esnada en çok güvendiği kissi olan Ubey b. Ka'b’a okutmuştur. Bu açıdan bu rivayet Allah Rasûlü'nün okuma ve yazma bilmediğini ortaya koymaktan uzaktır.

5- Hz. Peygamber'in vahiy kâtipleri arasinda yer alan Abdullah b. Sa'd b. Ebî Serh'in Rasûlüllah'ın okuma ve yazma bilmediğinden istifade ederek vahye müdahalede bulunması/kendisine söylenilenleri bilerek yanlış yazması, vahyin güvenilirliğini zedelemektedir. Rasûlüllah'in okuma ve yazma bilmediğini kanıtlamak amaciyla böyle bir rivayete sarılmak, doğru bir yaklaşım değildir. Çünkü Allah Rasûlü okuma ve yazma bilmese bile, vahyin yanlış yazılmasına bir şekilde engel olurdu. Hatta bu rivayeti geçersiz kılacak başka bir rivayetten bahsedilmektedir. Aynı şahsın bu tarzdaki yaklaşımlarına Hz. Peygamber'in müdahale ettiği ve doğrusunu yazması konusunda onu uyardığı belirtilmektedir. 58

6- Medine'ye gelen Sakîf heyeti, Hz. Peygamber'den İslâm'in yasakladığı zina, içki ve riba gibi bazı yasakların kendilerine uygulanmamasını talep etmiş ve bunların resmi belgeye yazılmasını talep etmişlerdir. Bu yazılı belgede yer alan ribanın serbest olacağ kısmı okununca Hz. Peygamberin "ضع يدي عليها" "Elimi o cümlenin üzerine koy" demesi, onun mutlak anlamda okuma ve yazma bilmediğine delil teşkil etmez. Çünkü bizler de böyle durumlarda "O yazıyı bana gösterir misin?" veya "Elimi o yazının üzerine koyabilir misin?" diye talepte bulunabiliriz. Böyle bir istek, okuma ve yazma bilinmediğini göstermez.

58 Ahmed b. Hanbel, Müsned, III, 121, 245. 
7- Hz. Peygamber'in gelen vahiyleri zihninde tutabilmek için kendisini zorlaması ve onları vahiy kâtiplerine yazdırmas1, onun üstlendiği sorumluluk konusundaki titizliğini ve işini sağlam yaptığını göstermektedir. Bu sebeple onun bu şekilde davranmas1, okuma ve yazma bilmediğiyle ilgili değildir.

8- Gerek Mekke döneminde gerekse de Medine döneminde $\mathrm{Hz}$. Peygamber'in etrafinda bulunan Hz. Ebû Bekir, Hz. Ömer, Hz. Osman ve Hz. Ali gibi sahâbîler okuma ve yazma biliyordu. Gelen vahiylerin yazıya geçirilmesi bunun en güzel örneğidir. Hz. Ömer'in Müslüman olması esnasında, kız kardeşi Fâtıma ve eniştesi Saîd b. Zeyd'in okudukları Tâhâ sûresinin yazılı olduğu sahifeyi okuması, ${ }^{59}$ bir gün $\mathrm{Hz}$. Ömer'in elinde kâğıt parçaları gören $\mathrm{Hz}$. Peygamber: "Onlar nedir? diye sorunca Hz. Ömer: "Tevrat'ın bir bölümü" şeklinde cevap vermesi,60 onun okuma ve yazmasının olduğunu göstermektedir. Abdülmuttalib b. Hâşim'in okur-yazar olduğu belirtilmektedir. ${ }^{61}$ Ayrıca Abdülmuttalib, on çocuğu olursa, birisini kurban edeceğine dair adağını yerine getirmek için oğullarına: "Her biriniz birer çubuk alın ve üzerine isimlerinizi yazıp bana getiriniz" ifadesi, $\mathrm{Hz}$. Peygamber'in amcalarının da okuma ve yazma bildiğini göstermektedir. ${ }^{62}$ Bunlardan daha önemlisi $\mathrm{Hz}$. Peygamber’in nübüvvetten önce gerek Mekke'de gerekse de Suriye-Şam, Bahreyn-Umman, Habeşistan ve Yemen gibi ülkelerde ticarî faaliyetlerde bulunmas1, ${ }^{63}$ onun okuma ve yazmadan uzak olmadığını göstermektedir.

9- Hudeybiye Antlaşmasında: "Bu Allah'in Rasûlu Muhammed ile Suheyl b. Amr arasinda imzalanan sulh antlaşmasıdır" cümlesinde yer alan "Allah'in Rasûlu" ifadesine itiraz edilince Hz. Peygamber'in onun: "Muhammed b. Abdullah" şeklinde değiştirilmesi emrine Hz. Ali'nin karş1 ç1kması üzerine onun: "ارني مكانها" "Onun yerini bana gös-

59 İbn Hişâm, es-Sîratü'n-Nebeviyye, I-II, 342-346.

60 Ebû Muhammed Abdullah Abdurrahman ed-Dârimî, Sünenü'd-Dârimî (İstanbul: Çağrı Yayınları, 1992), I, 95.

61 İbn Nedîm, el-Fihrist, Dâru'l-Ma'rife, Beyrut ts., s. 7-8.

${ }^{62}$ Muhammed b. İshâk b. Yesâr, Kitâbü'l-Meğâzî, tah. Muhammed Hamidullah (Konya: Hayra Hizmet Vakfi, 1981), 10.

63 Muhammed Hamidullah, İslâm Peygamberi, çev. Salih Tuğ (İstanbul: İrfan Yayımcılık, 1993), I, 48; Ahmet Turan Yüksel, "Bir Tacir Olarak Hz. Peygamber", Diyanet İlmi Dergi, Peygamberimiz Hz. Muhammed-Özel Say1- 2. Baskı (2003): 138-139. 


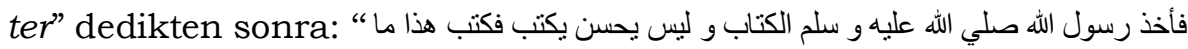
64 metni eline alarak Kureyş delegasyonunun istediği şekilde yazmas1, onun okuma ve yazma bildiğini göstermektedir.

Görüssleri

C- Hz. Peygamber'in Okuma-Yazma Bildiğini Savunanların

1- Hz. Peygamber ve Kureyş delegasyonu arasında gerçekleşen müzakerelerden sonra Hudeybiye barış antlaşması konusunda uzlaşma sağlanınca maddeler üzerinde görüşülmeye geçildi. İlk madde üzerindeki sorun aşıldıktan sonra ikinci maddenin yazılması için Allah Rasûlü kâtibi Ali b. Ebî Tâlib'e: "Bu Allah'ın Rasûlu Muhammed ile Suheyl b. Amr arasında imzalanan sulh antlaşmasıdır" cümlesini yazmasını istedi. Kureyş delegesi: "Biz senin Allah'ın Rasûlü olduğunu bilmiş ve tasdik etmiş olsaydik, seni Kâbe'yi ziyaret etmekten men etmez ve seninle savaşmazdik" diyerek buna da itirazda bulundu ve: "Rasûlüllah" kısmının kaldırılıp yerine "Muhammed b. Abdullah" yazılmasını talep etti. Bunun üzerine Rasûlüllah, Ali b. Ebî Tâlib'e "Rasûlüllah" lafzını silip "Muhammed b. Abdullah" yazmasını emretti. Ancak Ali b. Ebî Tâlib: "Rasûlüllah lafzını asla silemeyeceğini" söyleyince:

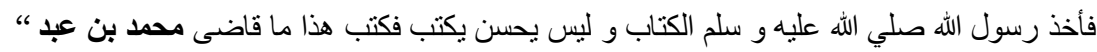

الله "Hz. Peygamber yazılı olan metni eline alarak tartışmalı kısmı sildi ve yazması çok iyi olmamasına rağmen iki taraf arasında sorun olan kısmı "Muhammed b. Abdullah" şeklinde değiştirerek ortaya çıkan problemi çözdü. 65

2- Hz. Peygamber, İsrâ gecesi cennetin kapısının üzerinde: "Sadaka verenin mükâfatı on kat, karz-ı hasen verenin mükâfatı ise on sekiz kattır " şeklinde yazılı bir cümle görmüştür. ${ }^{66}$ Yazılan bir şeyi okuyabilmek, yazmayı bilmenin bir parçasıdır. Bu durum, Rasûlüllah'ın okumayı ve yazmayı bildiğini göstermektedir. ${ }^{67}$

\footnotetext{
64 Buhârî, Meğâzî, 43.

65 Buhârî, Meğâzî, 43.

66 Süleyman b. Eş’as, Sünenü Ebî Dâvud (İstanbul: Çağrı Yayınları, 1992), Sadakât, 19.

67 Ebu'l-Abbâs Şihâbüddîn Ahmed b. Muhammed b. Ömer el-Hafecî, Şerhu'şŞifâ (Basım yeri ve tarihi yok), I, 117.
} 
3- Kabilelerini temsilen Hz. Peygamber'in yanına gelen Akra' b. Hâbis ve Uyeyne b. Hisn, kendilerine bir mektup/resmi belge vermesini istediler. Bunun üzerine Allah Rasûlü, Muâviye b. Ebî Süfyân'a istediklerini yazmasını söyledi. Ancak Uyeyne yazılan metni okuyamadığını belirtince Rasûlüllah yazılı belgeyi alarak içeriği hakkında onları bilgilendirmiştir. 68

4- Muâviye b. Ebî Süfyân yazı yazdığı bir esnada Hz. Peygamber: "Ey Muâviye! Yazında rakş ${ }^{69}$ yap" dedi. ${ }^{70} \mathrm{~Hz}$. Peygamber, Araplar arasında kullanılan alfabe ve yazı tarzının geliştirilip mükemmelleştirilmesi işi ile bizzat meşgul olmuştur. Benzer harf işaretlerinin birbirinden ayrılmalarını sağlamak üzere noktalama ve öyle anlaş11yor ki, birtakım özel işaretler kullanmak suretiyle en azından tenvin ihtiyacını karş1lamak üzere "harekeleme" usulünü düşünüp bulmuştur. ${ }^{71}$

5- Hz. Peygamber: "Biriniz besmeleyi yazdiğr zaman "لرحمن" kelimesinde bulunan "ק" ile "ن' arasinı uzatsın." "Besmeleyi yazdiğin zaman "w"in dişlerini belli et." "İtiyaçlarının kolay bir şekilde görülebilmesi için Besmelede bulunan "w”i güzel yazınız." Ayrıca Rasûlüllah, Muâviye b. Ebî Süfyân'a: "Ey Muâviye! Mürekkebi ayarla, kalemin ucunu düzgün kes, "ب"yi açığa çıkart, "w”in dişlerini belirt "p"in gözünü doldurma, "الرحمن" kelimesini uzatarak yaz ve "الرحيج" "kelimesinin de yazllsşına dikkat et"72 tavsiyelerinde bulunarak yazı yazarken uyması gereken kuralları belirtmiştir.

6- Allah, Hz. Peygamber'e her konuya ait bilgi ve güç vermiştir. Onda hesap yapma, yazı yazma ve okuma, şiir söyleme, ensâb malûmatı vs. gibi konularda toplu bir şekilde mütekâmil bir kuvvet ve iktidar vardır. Ancak ondaki bütün bu güçler, nübüvvetle daha ulvî bir yöne yöneltilmiş ve o, bunlarla boşuna uğraşmamıștır. Bu,

68 Ahmed b. Ali b. Hacer, Fethu'l-Bârî bi Şerhi Sahîhi'l-Buhârî (Beyrut: Dâru'1Ma'rife, ts.), VII, 504; Hafâcî, Şerhu'ş-Şifâ, I, 117.

69 Rakş, her harfin uygun olan noktasını koymaktır. Celâlüddîn Ebu'l-Fazl Abdurrahman es-Suyûtî, Tedrîbü'r-Râvî fî Şerhi Takrîbi'n-Nevevî (Beyrut: Daru'l-Fikr, 1993), 280.

70 Suyûtî, Tedrîbü'r-Râvî, 280.

${ }^{71}$ Hamidullah, İslâm Peygamberi, II, 761.

72 Ebu'l-Fazl Iyâz b. Musa b. Iyâz, eş-Şifâ bi Ta'rîfi Hukûki'l-Mustafâ (Beyrut: Dâru'l-Erkam, ts.), I, 313. 
idrak edilmeli ve ona acizlik isnadı ile imkân dâhilinde olan her şeyden imtina ederek daha iyisine yönelmenin farklı farklı şeyler olduğu bilinmelidir. ${ }^{73}$

7- Hz. Peygamber mükemmel bir şekilde okuma ve yazma biliyordu. Getirdiği ibadet şekillerinin birçoğunun İbrânî âyinlerinin aynısı olması, Kur'ân'da mevcut menkıbelerin büyük çoğunluğunun mukaddes kitaplarda bulunması, onun bunları önceden okuyarak kendine mâl ettiğine açıkça delalet ediyor. Ancak o, okuma ve yazma bildiğini muâsırlarından ve hatta birçok ashâbından bile maharetle saklamıştı. ${ }^{74}$

\section{D- Görüşlerin Değerlendirilmesi}

1- Hz. Peygamber'in okuma ve yazma bildiğini gösteren en önemli delil; Hudeybiye Antlaşması'ndaki tavrıdır. Buhârî'nin açık ve net ifadelerine göre Rasûlüllah, eline aldığ sahifeye anlaş1lır bir şekilde Kureyş delegasyonu Süheyl b. Amr'ın isteği doğrultusunda " محمد "بن عبد الله ifadesini yazmıştır. Mâtürîdî, Hz. Peygamber’in iyi sevide olmasa da okuma-yazma bildiğini belirtmektedir. ${ }^{75}$ Ayrıca, Muâviye b. Ebî Süfyân tarafından yazılan metni anlayamadıklarını söyleyen kabile reislerine metinin muhtevası hakkında onları tatmin edecek şekilde bilgilendirmesi, Muâviye b. Ebî Süfyan'a daha okunaklı ve anlaşılır bir şekilde yazmasını söylemesi, onun okuma ve yazma bildiğini gösteren tarihi delilerdir.

2- Hz. Peygamber'in, İsrâ gecesi cennetin kapısının üzerinde: "Sadaka verenin mükâfatı on kat, karz-ı hasen verenin mükâfatı ise on sekiz kattır" şeklinde yazılı bir cümle görmesi, onun okuma ve yazma bildiğine delil gösterilemez. Çünkü metafizik bir âlemde gerçeklesstiği vurgulanan bir olayın, maddî bir özelliği olan dünya hayatıyla kıyaslanarak bir sonuca ulaşılması doğru olmaz. İki âlemin yapıları birbirinden farklıdır. Bu sebeple insanın mahiyetini bilmediği bir âlemde gördüklerini ve yaşadıklarını gerçek hayatla ilişkisini

73 Ebû Osman Amr b. Bahr el-Câhız, el-Beyân ve’Tebyîn (Beyrut: elMektebetü'l-Asriyye, 2014), 609-610; Önkal, "Hz. Peygamber'in Ümmîliği", 255.

${ }^{74}$ Leon Caetani, İslâm Tarihi, çev. Hüseyin Cahid Yalçın (İstanbul: Tanin Matbaas1, 1924), IX, 158-166.

75 Mâtürîdî, Te'vîlâtü Ehli’s-Sünne, III, 491. 
kurmaya çalışarak bir kanaate ulaşması, ilmî ve akademik yaklaşımdan oldukça uzaktır.

3- Hz. Peygamber'e her konuda bilgi verildiğinin iddia edilmesi ve bu şekilde üstünlüğünün ortaya konulmaya çalış1lması, onun şanının ve derecesinin yükseltme gayretinin bir sonucudur. Onda bir eksiklik olduğunu düşünerek böyle yaklaşımlar içerisinde bulunmanın ona bir üstünlük kazandırmayacağı muhakkaktır. Bu sebeple aşırılığa kaçarak onu gereksiz bir şekilde olduğundan fazla göstermeye çalışmanın kazanımlar noktasında hiçbir faydası yoktur.

4- Leon Ceatani'nin, Hz. Peygamber hakkındaki ithamlarını ve düşüncelerini kabul etmek mümkün değildir. Rasûlüllah'ın, Kur'ân'da yer alan menkibelerin büyük bir çoğunluğunu diğer kutsal kitaplardan intihal ederek oluşturduğunu iddia etmek akıl, insaf ve izan ölçülerine aykırı bir yaklaşım olduğu gibi, herhangi bir delilden ve akademik üsluptan da oldukça uzaktır. Ayrıca Allah Rasûlü'nün okuma ve yazma bildiğini muasırlarından ve en yakın arkadaşlarından gizlediğini iddia etmek, gerçeklerle örtüşmemektedir. Hz. Peygamber hem nübüvvet öncesi hem de sonrası Medine'ye hicret edinceye kadar Mekke'de yaşamıştır. Mekke'nin nüfus yapısı ve yakın akraba ilişkileri, böyle bir durumun gizlenemeyeceğini göstermektedir. Ayrıca Rasûlüllah'ın hayatını en ince ayrıntılarına kadar belirten kaynaklar, onun bu özelliği hakkında bir cümle bile bahsetmezler. Hz. Peygamber'den bin üç yüz sene sonra yaşayan Leon Ceatani mi, bu bilgiye ulaştı? Hiçbir mesnede dayanmaksızın böyle bir yaklaşımda bulunmak, nefretin, kindarlığın, öfkenin ve düşmanlığın tezahürüdür. Bir insanın böyle bir bilgiyi uzun süre diğerlerinden saklamas1 mümkün değildir. Bu konuda kişi ne kadar uğraşırsa uğraşsın, hayatının belli bir döneminde bilerek veya bilmeyerek gizemli durumunu açığa vurabilir ve kurmaya çalıştığ Diğer taraftan asabiyetin ve kabileciliğin yaygın olduğu Mekke toplumunda Hz. Peygamber'in kabilesi olan Hâşimoğullarının konumu, diğer kabilelere göre daha iyi seviyedeydi. Bu sebeple onun dinî bir eğitim süzgecinden geçerek kendisini geleceğe hazırlamas1, akrabalarının gözünden kaçacak bir durum değildir. Tebliğ döneminde bile en azılı düşmanları onu, böyle bir konuyu gündeme getirerek propaganda faaliyetinde bulunmamıslardır. Bir bardak suda firtınalar koparan muhalifler, insanların onun etrafinda toplanmalarına mani olmak 
için bu durumu firsat bilirlerdi. Yaşanılan dönemde etkisi olmayan bir konuyu asırlar sonra gündeme taşımak ve çeşitli iftiralarla onun üzerinde temel inşa etmeye çalışmak, bilimsellikten ve inandırıcılıktan uzaktır.

\section{Sonuc}

أم fiilinin ism-i mensubu olan الأمتى kelimesi, bir şeyin asl1, okuma-yazma bilmeyen, anasından doğduğu gibi kalan ve Arap ümmetine veya Ümmü'l-Kurâ'ya (Mekke toplumuna) mensup olan kişi anlamlarına gelmektedir. Kur'ân-1 Kerîm'de “ümmî" kelimesi altı yerde geçmektedir. A'râf sûresinin 157. ve 158. âyetlerinde Hz. Peygamber kastedilerek tekil olarak "ümmî-nebî-rasûl" şeklinde sıfat olarak geçmektedir. Bakara 78, Âl-i İmrân 20, 75 ve Cum'a 2. âyetlerde ise çoğul olarak kullanılan "ümmiyyûn" kelimesiyle de Müslüman Araplar, müssrik Araplar ve Ehl-i kitap kastedilmektedir. Özellikle konumuzla ilgili olan âyet A'râf sûresinde $\mathrm{Hz}$. Peygamber'in sıfat olarak geçen "ümmî" kelimesi, okuma-yazma bilmeyen anlamında kullanıldığı için onun okuma-yazma bilmediği şeklinde yorumlanmıştır. Âyetin siyak ve sibakından böyle bir anlam çıkarmak doğru değildir. Kelime gramatik olarak sıfat özelliğinde olduğundan Hz. Peygamber'in mensup olduğu topluma işaret etmektedir. Yani onun Mekkeli olduğuna vurgu yapılmaktadır.

“Sen şu Kur'an'dan önce hiçbir kitap okumuyor ve onu sağ elinle yazmıyordun."76 âyeti bağlamından koparılarak Hz. Peygamber'in okuma-yazma bilmediğinin en önemli delili olarak kabul edilmiștir. $\mathrm{Bu}$ âyetin konusu Rasûlüllah'in okur-yazar olup olmadığını belirtmek değildir. Amaç; vahyin Hz. Peygamber tarafından yazılmadığını ve onun bu konuda herhangi bir eğitim süzgecinden geçmediğini ortaya koyarak vahyin kaynağının Allah olduğunu tescil etmektir. Bu sebeple bu âyet, "İnkâr edenler, "Bu Kur'ân, Muhammed'in uydurduğu bir yalandan başka bir şey değildir..." "(Bu Kur'ân başkalarından) yazıp aldığı öncekilere ait efsanelerdir. Bunlar ona sabah akşam

\footnotetext{
76 Ankebût: 29/48.

${ }^{77}$ Furkân: 29/4.
} 
okunmaktadir, dediler."78 "Andolsun ki biz, onların, "Kur'ân't ona bir insan ögretiyor" dediklerini biliyoruz."79 âyetlerinde Hz. Peygamber'e karşı müşrikler tarafından yöneltilen ithamlara bir cevap özelliği taşımaktadır.

Abdülmuttalib b. Hâşim’in, Hz. Peygamber'in amcalarının, yakın arkadaşlarından olan Hz. Ebû Bekir'in, Hz. Ömer'in, Hz. Osman'ın, Hz. Ali'nin ve vahiy kâtiplerinin okuma-yazma bilmesi, Mekke toplumunda okuma-yazma oranının sanıldığı kadar az olmadığını göstermektedir. Bunlardan daha da önemlisi, Rasûlüllah'in nübüvvetten önce ticârî faaliyetlerde bulunması ve bu amaçla Suriye-Şam, Bahreyn-Umman, Habeşistan ve Yemen'e çeşitli zamanlarda seyahatlerde bulunması, onun okuma-yazma eyleminden uzak olmadığını göstermektedir. Ayrıca onun, Hudeybiye Antlassması'nda "Muhammed b. Abdullah" ifadesini yazması, yazılı belgenin içeriği hakkında Uyeyne b. Hısn'a bilgi vermesi, Muâviye b. Ebî Süfyân'a okunaklı ve güzel yazmasını tavsiye etmesi, onun okuma ve yazma konusunda bilgisi olduğunu ortaya koymaktadır. Bu sebeple Allah Rasûlü'nün nübüvvetten önce okuma-yazma bilmediğini, nübüvvetten sonra kendini ifade edebilecek kadar okuma yazma biliyordu, şeklinde bir değerlendirmede bulunmak doğru değildir. O, risâletten önce en az Mekke toplumunda okuma-yazma bilen diğer bireyler kadar okuma-yazma biliyordu. Kur'ân-1 Kerîm'i onun okuma-yazma bilmediğine referans olarak kullanmak uygun değildir. Çünkü Kur'ân, Hz. Peygamber’in okuma-yazma bilmediğine değil, vahyin kaynağının o olmadığına vurgu yapmaktadir.

\section{Kaynakça}

Afzalur Rahman, Sìret Ansiklopedisi, çev. Komisyon. İstanbul: İnkılâb Yayınlar1, 1996.

Ahmed b. Hanbel, Müsned. İstanbul: Çağrı Yayınları, 1992.

Buhârî, Ebû Abdullah Muhammed b. İsmail, Sahîhu'l-Buhârî. İstanbul: Çağrı Yayınları, 1992.

Câbirî, Muhammed Âbid, Kur'ân'a Giriş, çev. Muhammed Çoşkun. İstanbul: Mana Yayınları, 2013.

\footnotetext{
78 Furkân: 25/5.

79 Nahl: 16/103.
} 
Caetani, Leon, İslâm Tarihi, çev. Hüseyin Cahid Yalçın. İstanbul: Tanin Matbaas1, 1924.

Câhız, Ebû Osman Amr b. Bahr, el-Beyân ve'Tebyîn.Beyrut: elMektebetü'1-Asriyye, 2014.

Dârimî, Ebû Muhammed Abdullah Abdurrahman, Sünenü'd-Dârimî. İstanbul: Çağrı Yayınları, 1992.

Demil, Emine, "Ümmî Kavramı ve Hz. Muhammed'in (S.A.V) Ümmiliği”. Ilhiyat Araştırmaları Dergisi, say1 7 (2017): 91-123.

Ebû Dâvud, Süleyman b. Eş'as, Sünenü Ebî Dâvud. İstanbul: Çağn Yayınları, 1992.

Fîrûzabâdî, Mecdüddîn Muhammed b. Ya'kûb, el-Kâmûsu'l-Muhît. Beyrut: Müessesetü'r-Risâle, 1987.

Hafâcî, Ebu'l-Abbâs Şihâbüddîn Ahmed b. Muhammed b. Ömer, Şerhu'ş-Şifâ. basım yeri ve tarihi yok.

Hamidullah, Muhammed, İslâm Peygamberi, çev. Salih Tuğ. İstanbul: İrfan Yayımc1lik, 1993.

İbn Hacer, Ahmed b. Ali b. Hacer, Fethu'l-Bârî bi Şerhi Sahîhi'lBuhârî. Beyrut: Dâru'-Ma'rife, ts.

İbn Hişâm, Abdülmelik, es-Sîratü'n-Nebeviyye. Kahire: Dâru İbn Kesîr, ts.

İbn İshâk, Muhammed b. İshâk b. Yesâr, Kitâbü'l-Meğâzî. tah. Muhammed Hamidullah. Konya Hayra Hizmet Vakfi, 1981.

İbn Kesîr, Ebu'l- Fidâ, el-Bidâye ve'n-Nihâye. Kahire: Dâru'l-Hadîs, 1994.

İbn Manzûr, Ebu'l-Fadl Cemâlüddîn Muhammed b. Mmukerram, Lisânü'l-Arab. Beyrut: Dâru Sâdır, 1990.

İbn Nedîm, el-Fihrist. Beyrut: Dâru'l-Ma'rife, ts.

İbn Sa'd, Muhammed, et-Tabakâtü'l-Kübrâ. Beyrut: Dâru'1-Kütübi'lIlmiyye, 1990.

Kâdî Iyâz, Ebu'l-Fazl Iyâz b. Musa b. Iyâz, eş-Şifâ bi Ta'rîfi Hukûki'lMustafâ. Beyrut: Dâru'1-Erkam, ts.

Kettânî, Muhammed Abdülhay b. Abdülkebir, et-Terâtîbü'l-İdâriyye. çev. Ahmet Özel. İstanbul: İz Yayınclık, 1990. 
Kurtubî, Ebû Abdullah Muhammed b. Abdullah, el-Câmî li Ahkâmi'lKur'ân. Kahire: Dâru'l-Hadîs, 2010.

Kurtubî, Ebû Abdullah Muhammed b. Ahmed, el-Câmî li Ahkâmi'lKur'ân. Kahire: Dâru'l-Hadîs, 2010.

Mâtürîdî, Ebû Mansûr Muhammed b. Muhammed b. Mahmud, Te'vîlâtü Ehli's-Sünne, Müesesetü'r-Risâle, Beyrut 2004.

Mertoğlu, Mehmet Suat, "Ümmî". Türkiye Diyanet Vakfı İslâm Ansiklopedisi. 42: 309-310. İstanbul: TDV Yayınları, 2012.

Mevdûdî, Seyyid Ebu'l-Alâ, Tarih Boyunca Tevhid Mücadelesi ve Hz. Peygamber'in Hayatı, çev. Ahmed Asrar. İstanbul: Pınar Yayınlar1, 1992.

Mevdûdî, Seyyid Ebu'l-Alâ, Tefhîmü'l-Kurân, çev. Komisyon. İstanbul: İnsan Yayınları, 1991.

Müslim, Ebu'l-Huseyin Müslim b. Haccâc, Sahîhu Müslim. İstanbul: Çağrı Yayınları, 1992.

Önkal, Ahmet, "Hz. Peygamber'in Ümmîliği”. Konya Selçuk Üniversitesi Illahiyat Fakültesi Dergisi, sayı 2 (1986): 249-262.

Râğıb el-İsfehânî, Müfredâtü Elfâzi'l-Kurân. Dimeşk: Dâru'l-Kalem, 1992.

Rizâ, Muhammed, Muhammed. Beyrut: Dâru'l-Kalem, 2003.

Suyûtî, Celâlüddîn Ebu'l-Fazl Abdurrahman, Tedrîbü'r-Râvî fì Şerhi Takrîbi'n-Nevevî. Beyrut: Daru'l-Fikr, 1993.

Şâhin, Abdu's-Sabûr, "Hz. Muhammed Okumayı ve Yazmayı Biliyor muydu?". çev. Tayyar Altıkulaç. Diyanet İlmi Dergi 12, say1 4 (1973): 195-200.

Şen, Ziya, "Kur'ân'da Ümmî Kavramı ve Hz. Peygamber'in Ümmiliği". İslâmî Illimler Dergisi, say1 2 (2006): 203-218.

Taberî, Ebû Ca'fer Muhammed b. Cerîr, Câmiu'l-Beyân an Te'vîli Âyi'l-Kur'ân. Kahire: Dâru'l-Hadîs, 2010.

Taberî, Ebû Ca'fer Muhammed b. Cerîr, Târîhu'l-Ümem ve'l-Mülûk. Beyrut: Dâru'l-Kütübi'l-Ilmiyye, 1997.

Yazır, Muhammed Hamdi, Hak Dini Kur'ân Dili İstanbul: Eser Neşriyat ve Dağıtım, İ 1979. 
Yılmaz, Muhammed, İbadete Karşı Toplumsal Tavırlar Ankebût Sûresi Örneği. İstanbul: Erkam Yayınları, 2016.

Yüksel, Ahmet Turan, "Bir Tacir Olarak Hz. Peygamber". Diyanet İlmi Dergi, Peygamberimiz Hz. Muhammed-Özel Say1- 2. baskı (2003): 137-148.

Zemahşerî, Ebu'l-Kâsım Cârullah Mahmûd b. Ömer b. Muhammed, el-Keşşâf. Lübnan: Dâru'l-Kütübi'l-Ilmiyye, 2009.

Zemahşerî, Ebu'l-Kâsım Cârullah Muhammed b. Ömer b. Muhammed, el-Keşşâf. Beyrut: Dâru'1-Kütübi'l-Ilmiyye, 2009. 